\title{
6 The development of the South Korean film industry in 2018
}

\author{
Korean Film Council
}

\section{Market volume of the 2018 South Korean film industry}

In 2018, the number of total admissions in South Korean cinemas totaled 216.39 million, 1.6 percent less than the previous year in terms of numbers. This decrease, however, is not significant, as the admissions figure for the past six years has remained relatively stable with slight fluctuations after reaching the 210 million mark in 2013. Film sales have continued the trend of a slight increase (Korean won (KRW) 1.8140 trillion), but this reflects an increase in special screenings and ticket fees, centered on multiplex chains in April rather than the structural growth of the market itself. With the steep decline in population growth, bordering on the negative, and the fact that South Korean film attendance per person is already one of the highest in the world, market growth in the form of film admissions shown in the past is not likely to be observed in the future. The rise of different activities other than films is also a threat to the film industry.

In 2018, the digital and online film market, on the contrary, totaled KRW 473.9 billion, an 8.6 percent increase from the previous year. Because the current measurements of the online film market fail to reflect the multitude of services available in the market, the actual size of the online film market in South Korea is expected to be greater than this estimate.

In terms of exports, film exports maintained similar levels to previous years. However, service exports, having relied absolutely on the Chinese market, halved, reducing the total sales by 34 percent to KRW 88.5 billion.

Overall, the total volume of the South Korean film market in 2018 was estimated at KRW 2.3764 trillion, reflecting an increase of 2.1 percent on the previous year (see Table 6.1, Figure 6.1). ${ }^{1}$

\section{Theater chain and distribution}

In 2018, the theater market did not deviate from its trend of low growth. The total admissions figure showed a reduction of 1.6 percent to 216.39 million (219.87 million in 2017), while the total film sales figure reached KRW 1.814 trillion, a 3.3 percent increase from the previous year (KRW 1.7566 trillion), 
Table 6.1 Sales figures for the South Korean film industry, 2009-2018 (KRW 100 million)

\begin{tabular}{|c|c|c|c|c|c|c|c|c|c|c|c|}
\hline Classification & 2009 & 2010 & 2011 & 2012 & 2013 & 2014 & 2015 & 2016 & & 2017 & 2018 \\
\hline Ticket sales & 10,941 & 11,684 & 12,358 & 14,551 & 15,513 & 16,641 & 17,154 & 17,432 & & 17,566 & 18,140 \\
\hline Ratio (\%) & 91.3 & 88.1 & 85.5 & 85.0 & 82.3 & 82.1 & 81.2 & 76.7 & & 75.5 & 76.3 \\
\hline Additional markets & 888 & 1,109 & 1,709 & 2,158 & 2,676 & 2,971 & 3,349 & 4,125 & & 4,362 & 4,739 \\
\hline Ratio (\%) & 7.4 & 8.4 & 11.8 & 12.6 & 14.2 & 14.7 & 15.8 & 18.1 & & 18.7 & 19.9 \\
\hline Overseas In KRW 100 million* & 155 & 462 & 382 & 414 & 651 & 664 & 628 & Film & 509 & 460 & 458 \\
\hline exports & & & & & & & & service & 664 & 883 & 427 \\
\hline & & & & & & & & subtotal & 1,173 & 1,343 & 885 \\
\hline In US\$ $10,000^{*}$ & 1,412 & 4,222 & 3,487 & 3,782 & 5,946 & 6,308 & 5,550 & Film & 4,389 & 4,073 & 4,160 \\
\hline & & & & & & & & service & 5,720 & 7,806 & 3,876 \\
\hline & & & & & & & & subtotal & 10,109 & 11,879 & 8,036 \\
\hline Ratio (\%) & 1.3 & 3.5 & 2.6 & 2.4 & 3.5 & 3.3 & 3.0 & 5.2 & & 5.8 & 3.7 \\
\hline Total & 11,984 & 13,255 & 14,449 & 17,123 & 18,840 & 20,276 & 21,131 & 22,730 & & 23,271 & 23,764 \\
\hline Ratio (\%) & 100 & 100 & 100 & 100 & 100 & 100 & 100 & 100 & & 100 & 100 \\
\hline
\end{tabular}

Source: Korean Film Council.

Notes: * Film and service sales had been included since 2016.

Conversion to KRW follows 1 US\$ $=1,101.47 \mathrm{KRW}$ (average purchase rate for 2018). 


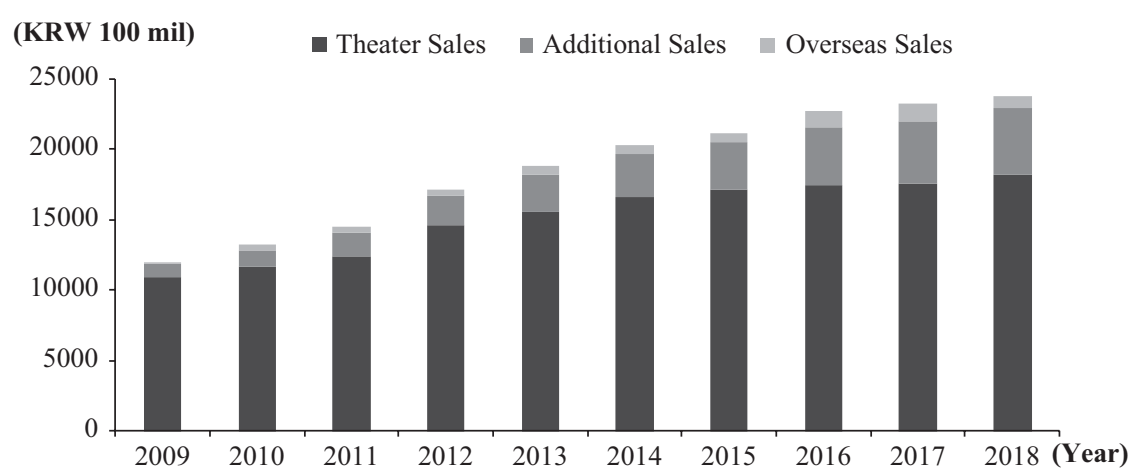

Figure 6.1 Sales figures for the South Korean film industry, 2009-2018.

its highest record. The average total ticket cost for the year 2018 was KRW 8,286 , reflecting an increase of 4.6 percent from the previous year (KRW $7,925)$. This was the reason for the general increase in theater sales. The total admissions figure for South Korean films showed a reduction of 3.3 percent to 110.15 million (113.90 million in the previous year), while the total film sales figure reached KRW 912.8 billion, a 1.1 percent increase from the previous year (KRW 902.7 billion). The market share of South Korean films reached 50.9 percent, a decrease of 0.9 percent from the previous year, successfully maintaining the slight increase it had enjoyed for eight years since 2011. The average number of films seen per capita was 4.18 , reflecting a reduction of 0.07 over the previous year. However, South Korea still has one of the highest average numbers of films seen per capita, which seems to indicate that the film industry will maintain its low-growth trend without large changes.

The distributor market share ranking reflected a significant change, with Lotte's ascent to first place with 17.1 percent of the shares from its second place in the previous year, followed by the outstanding performance of Disney (Korea) of 13.9 percent in second place. CJ ENM, the undisputed leader of the market for 15 years, was relegated to third place with a 13.3 percent share.

\section{Digital online markets}

The size of the digital and online market in 2018 reached KRW 473.9 billion, an increase of 8.6 percent from the previous year, thanks to the growth of TV video-on-demand (VOD) markets through Internet Protocol TV (IPTV) and digital cable TV. Even though the Internet VOD market has seen serious growth in the wake of fierce competition between domestic and international over-the-top (OTT) services, the South Korean digital and online film market is still dominated by TV VOD and its share of 83 percent. The highest grossing film in the TV VOD market was Along with the Gods: The Two 


\section{Korean Film Council}

Worlds with more than 1.7 million views, followed by strong performances by crime dramas and action films.

The Internet VOD market saw a reduction in total sales of 3.2 percent due to tightened regulations. The DVD and Blu-ray market also saw the continuation of its dwindling performance.

\section{Exports}

2018 saw significant damage to the export prospects of South Korean films from macro-political events. 2018's export sales crashed to US\$80.36 million. While the export of films (US\$41.6 million) stayed the same as the previous year, service export decreased by 50.35 percent from the previous year (US\$78.06 million to US\$38.76 million). This reflected the over-reliance of South Korean firms on the Chinese market that drove most of the expanding technological services industry.

Taiwan topped the export market for the first time, and 2018 once again reaffirmed the dominance of the Chinese-speaking markets (China, Hong Kong, Singapore, etc.) with the share of sales at 48.2 percent.

Overseas films set in Korea were estimated to have collectively spent US\$3.39 million in expenditure, a 57 percent decrease from the previous year. While 2018 did not have blockbuster-level films like Black Panther in 2017, it was also notable that six Chinese films included locations in Korea.

\section{Data interpretation of the 2018 South Korean film industry}

\section{Theaters and multiplexes}

The number of theaters nationwide increased from 452 in 2017 to 483 in 2018, an increase of 31, while the number of screens increased by 171 to 2,937 (see Table 6.2). Multiplexes accounted for 79.5 percent of the total number of theaters.

The distribution and investment company NEW started its screening business in 2017, and opened five theaters called CineQ. Theater chains like this vertically integrated investment with distribution and screening, occupied 381 affiliated multiplexes, and the number of its screens totaled 2,727.

In terms of administrative regions, 50 administrative regions had no theater at all, and two of them had a population of over 200,000 .

\section{Major players and market structure}

2018 did not see any changes in the fundamental structure of the South Korean film industry or the vertical organization of major film companies from production to distribution and screening. Likewise, there were no changes in the trend of centralization of screening and distribution markets. On the contrary, NEW, the latest newcomer to join the screening market in 
Table 6.2 Major statistical indicators for the South Korean film industry, 2009-2018

\begin{tabular}{|c|c|c|c|c|c|c|c|c|c|c|c|}
\hline \multicolumn{2}{|l|}{ Classification } & \multirow{2}{*}{$\frac{2009}{15,696}$} & \multirow{2}{*}{$\begin{array}{l}2010 \\
14,918\end{array}$} & \multirow{2}{*}{$\begin{array}{l}2011 \\
15,972\end{array}$} & \multirow{2}{*}{$\begin{array}{l}2012 \\
19,489\end{array}$} & \multirow{2}{*}{$\frac{2013}{21,335}$} & \multirow{2}{*}{$\frac{2014}{21,506}$} & \multirow{2}{*}{$\begin{array}{l}2015 \\
21,729\end{array}$} & \multirow{2}{*}{$\begin{array}{l}2016 \\
21,702\end{array}$} & \multirow{2}{*}{$\begin{array}{l}2017 \\
21,987\end{array}$} & \multirow{2}{*}{$\begin{array}{l}2018 \\
21,639\end{array}$} \\
\hline Admission (in 10,000) & Total admissions & & & & & & & & & & \\
\hline & South Korean films & 7,641 & 6,940 & 8,287 & 11,461 & 12,729 & 10,770 & 11,293 & 11,655 & 11,390 & 11,015 \\
\hline & Admission share (\%) & 48.7 & 46.5 & 51.9 & 58.8 & 59.7 & 50.1 & 52.0 & 53.7 & 51.8 & 50.9 \\
\hline & Foreign films & 8,055 & 7,978 & 7,685 & 8,028 & 8,606 & 10,736 & 10,436 & 10,047 & 10,597 & 10,624 \\
\hline & Admission share (\%) & 51.3 & 53.5 & 48.1 & 41.2 & 40.3 & 49.9 & 48.0 & 46.3 & 48.2 & 49.1 \\
\hline \multirow[t]{2}{*}{ No. of films released* } & South Korean films & 118 & 140 & 150 & 175 & 183 & 217 & 232 & $\begin{array}{l}302 \\
(167)\end{array}$ & $\begin{array}{l}376 \\
(164)\end{array}$ & $\begin{array}{l}454 \\
(194)\end{array}$ \\
\hline & Foreign films & 243 & 286 & 289 & 456 & 722 & 878 & 944 & $\begin{array}{l}1,218 \\
(411)\end{array}$ & $\begin{array}{l}1,245 \\
(456)\end{array}$ & $\begin{array}{l}1,192 \\
(534)\end{array}$ \\
\hline \multicolumn{2}{|c|}{ No. of screens nationwide } & 2,055 & 2,003 & 1,974 & 2,081 & 2,184 & 2,281 & 2,424 & 2,575 & 2,766 & 2,937 \\
\hline \multicolumn{2}{|c|}{ No. of theaters nationwide } & 305 & 301 & 292 & 314 & 333 & 356 & 388 & 417 & 452 & 483 \\
\hline \multicolumn{2}{|c|}{$\begin{array}{l}\text { Average film admissions per capita } \\
\text { Return on investment for South }\end{array}$} & 3.15 & 2.92 & 3.15 & 3.83 & 4.17 & 4.19 & 4.22 & 4.20 & 4.25 & 4.18 \\
\hline \multicolumn{2}{|c|}{ Korean films** $(\%)$} & -13.1 & -11.0 & -16.5 & 15.9 & 16.8 & 7.6 & 4.0 & 17.6 & 18 & -17.3 \\
\hline
\end{tabular}

Source: Korean Film Council.

Notes: * No. of films released refers to the number of films that exceeded 40 screenings per year (daily screening in a week for a single theater yields approximately 40 screenings). This indicator has been included since 2016.

** Profit rate analysis focused on films "exceeding KRW 1 billion in total production cost" or films "screened in more than 100 theaters at its highest point" until 2016. In 2017, a new criterion of "films exceeding KRW 3 billion in actual production cost" was introduced to reflect the rising trend of production costs. 
2017, expanded the number of its CineQ theaters to five, perhaps signaling its move to rise as the fourth multiplex giant of the South Korean film industry. Another note is CJ ENM's drop from its position of absolute dominance from 2013 to 2017, ending up in third place for the first time, due to the poor performance of its projects and the excellent performance of its competitors, Lotte and Disney (Korea).

Certainly, it is still too early to draw any conclusions about CJ ENM's performance in the South Korean market based on its performance in 2018 alone. CJ ENM was launched in 2018 through a merger of CJ E\&M and CJ O Shopping, to expand the media content and platform projects to the area of merchandising. A comparison of the market capitalization in late 2018 shows that CJ CGV, the largest theater chain company in South Korea, has only one-third of the CJ-affiliated TV drama producer Studio Dragon, which in turn demonstrates CJ's interpretation of the future of media content industry.

The year 2018 was also characterized by the entrance of new players such as Merry Christmas, Acemaker Movie Works, and Haengnam to the distribution market, raising expectations for their activities from 2019 onward. Such developments show that the South Korean film industry may be standing on the edge of a zero-sum game between limited markets or a new way out through new movies.

\section{Market concentration}

The year 2018's screening market did not deviate from the trend of high concentration (Herfindahl-Hirschman Index 3,610); the largest accounted for 50 percent and the top three companies accounted for 97 percent of screenings, respectively. Future changes from this trend remain highly unlikely. If a distinction is made between affiliated multiplex and contract theaters, market concentration indicators tend to fall (HHI 2,353).

The distribution market reflected a slight increase in concentration, even though the market remains relatively dispersed compared to the screening market (the top one accounted for 16.9 percent, the top three accounted for 44.3 percent, HHI 1,030). However, concentration in South Korean film distribution remains significantly higher than the market average (the top one accounted for 25.8 percent, the top three accounted for 69.5 percent, HHI 1,871). The share of films ranking first to third in daily screening ratio has consistently increased over the past few years, eventually reaching 67.5 percent in 2018.

There were nine films that had more than a 40 percent screening ratio per day in 2018. Avengers: Infinity War had 21 days where its share remained over 40 percent, with the highest share reaching 77.4 percent. Along with the Gods: The Last 49 Days started with a 53.3 percent share and reached 59 percent on its fourth day, becoming the highest grossing film of 2018 with 12 million admissions. 


\section{Independent art films}

A total of 496 independent art films were released in South Korea in 2018. While the number of films released remained similar to the previous year, 2018 was also marked by a sharp drop in the number of admissions (-12.3 percent). This trend appears especially dangerous to the health of South Korean independent films, as 113 South Korean-produced independent films accounted for only 1.1 million admissions or 12.9 percent of the total. This is only 0.5 percent of total admissions in 2018, half of the previous 1 percent share that independent films had managed to maintain for the previous three years.

The highest-grossing independent art film in 2018 was What Happened to Monday that gained 900,000 admissions. Only 15 films had more than 100,000 admissions in 2018, and the documentary film Intention was the only South Korean film among them. Microhabitat was the second highest-grossing South Korean independent art film in 2018, but its admission performance of 59,110 would have only been in ninth place in terms of the previous year's records.

\section{Summary of the development of South Korean-produced films in 2018}

\section{Production costs and estimated ROI}

The sum of production costs for 186 films that saw "actual release"2 in 2018 (174 in the previous year) amounted to KRW 498.6 billion (KRW 458.2 billion in the previous year), with an average total production cost of KRW 2.68 billion (KRW 2.63 billion in the previous year) and an average pure production cost of KRW 2 billion (KRW 1.91 billion in the previous year). These represent a rise from the previous year's levels. The total sum of production costs for 40 commercial films that had a production cost of over KRW three billion (37 in the previous year), amounted to KRW 414 billion, with an average total production cost of KRW 10.34 billion (KRW 9.78 billion in the previous year) and an average pure production cost of KRW 7.9 billion (KRW 7.33 billion in the previous year).

The average estimated return on investment (ROI) for these 40 commercial films was estimated at -17.3 percent, a drastic drop from 2017's average (18 percent). After the positive shift of the ROI for South Korean films in 2012, their average ROI remained positive until 2017. The reason for this drastic drop is estimated to be the lack-luster performance of high-budget films in the box office with more than KRW 10 billion production cost, while profit rates also showed a decline for lower and mid-budget films with budgets of KRW 3-5 billion or 5-8 billion. 


\section{The underwhelming performance of South Korean films}

In 2018, South Korean films accounted for 50.9 percent of the total admissions in the theater, which had passed the 50 percent boundary for eight consecutive years. It seemed to show, at least on the surface, that there were no problems associated with their performance. However, a closer examination reveals that South Korean films performed quite poorly in 2018 and that both commercial films and independent art films showed this tendency.

While the film Along with the Gods broke several records in its second consecutive release since 2017, other heavy-budget commercial films capitalizing on the high seasons of New Year, summer vacation, mid-autumn day, and end-of-the-year periods failed to perform well, both critically and financially. A general investigation of the film budget in South Korean commercial films conducted in 2018 showed that the average production budget was KRW 7.9 billion, an increase of KRW 0.57 billion from the previous year. There were 40 films that had over KRW 3 billion budget, in particular, 2018 saw five more films costing over KRW 8 billion in production more than the previous year. An estimate of their ROI put the profitability of such films on a sizable crash. ${ }^{3}$ Certainly, this trend is only backed by estimates and will no doubt see some improvement once actual figures are included in the calculation. Nevertheless, most South Korean commercial films failed to perform beyond their break-even point and their critical performances were also found to be unsatisfactory. This fact is certainly a worrisome development. On the contrary, mid-to-low budget films between KRW 3-5 billion could break even and make a profit.

Such a gloomy performance extended to independent art films. Some 113 South Korean independent art films released in 2018 managed to attract only 1.1 million audiences, 0.5 percent of the total admissions. The documentary film Intention accounted for half of that figure ( 0.54 million), which shows that 112 independent art films shared 0.56 million moviegoers between them. That is even less than a day's figure for successful commercial films. Along with the continued calls for public support for the production and distribution of such films, a discussion of the future and sustainability of independent films seems to be required for the health of the South Korean film industry.

\section{Film production in the 52-hour working week}

The Labor Standards Act (Amendment) was passed by the National Assembly in February 2018. Film industry workers were excluded from the enforcement of the 52-hour working week before this amendment. This will result in the explosive surfacing of many problems hidden within South Korean film production. And even though the year's discussions and arguments have not yielded any fruitful results, the actual enforcement of the law planned in 2020 means that the South Korean film industry must find acceptable solutions to this dilemma during 2019. 


\section{"Me too" and gender equality in South Korean films}

The year of 2018 saw the discussions of abuse and inequality within the South Korean film industry surface with the continuation of the "Me Too" movement. Testimonials from victims of such abuse forced many male members of the industry to cease their public activity, and in some cases, a completed film was filmed again in the wake of testimonials.

March 2018 saw the establishment of the South Korean Film Gender Equality Center, an agency dedicated to supporting the victims of sexual abuse and the prevention of sexual abuse within the film industry. It was followed by the establishment of the Sub-committee on Gender Equality under the Korean Film Council in August, which laid the basis for macrolevel policies for gender equality. These discussions in 2018 have created plans to raise the mandatory gender percentage to $40-50$ percent in the Korean Film Council.

\section{Film statistics on female-produced films}

Of the 77 commercial films released in 2018, 10 films are directed by female directors (13.0 percent), 15 films are associated with female executive producers (19.5 percent), 23 films are produced by female producers (29.9 percent), 24 films feature female protagonists (31.2 percent), and 23 films are written by female screenwriters (29.9 percent), which reflect a general increase across all areas, excluding production and cinematography. In particular, 2018 featured the highest ratio of female directors and leads in the last five years.

The average admissions to films directed by female directors rose to 593,319 , which is an increase of 28.8 percent from the previous year and the fifth consecutive increase for the past five years. The average admissions to films with female leads rose to 572,858 , which is an increase of 41.4 percent from the previous year.

\section{Notes}

1 The total volume of the South Korean film market, as reported by the South Korean Film Council, refers to the sum of: (1) sales from film tickets sold at the theater; (2) sales from digital and online market (centered on TV VOD); and (3) overseas sales (film and service export). Strictly speaking, the volume of South Korean film market itself should include all sales generated by companies within the market. As such, the total volume of the South Korean film market is estimated to be much greater than the estimate provided here. For reference, the 2017 South Korean Film Industry Survey conducted by the Korean Film Council estimated the total volume of the market as KRW5.4947 trillion.

2 Some 194 films were regarded as "actual release," but eight of them were identified as not belonging to the South Korean investment and production system. To accurately calculate production cost, only 186 films were analyzed. The figure here is different from Table 6.2. 


\section{Korean Film Council}

3 The informal production cost survey conducted by the Korean Film Council at the beginning of each year, because of its timeframe, includes many films that did not pass through the primary balancing stages. In such a case, the survey uses the budget as a stand-in for the actual figures, which prevents the survey from accounting for the additional costs. In the commercial film ROI survey, conducted concurrently to the informal production cost survey, film rental sales are calculated by multiplying the total admissions figure of the South Korean commercial films with the previous year's average film rental sales per person. Consequently, a change in the film rental sales figure per person would mean that film rental sales as a whole would differ from the estimate. This is particularly significant as the average ticket cost rose by KRW 361 to total KRW 8,286 in 2018 (KRW 7,989 in 2017), which is expected to have increased the overall film sales for this year. Furthermore, fees and other costs (including incentives) are also calculated by multiplying the ratio of the previous year's fees and other costs by the estimated total sales of the year, and thus may be different from the estimated costs later on. 